Yu. Davydovskyi, O. ReVA, O. Artiukh, V. Kosenko

\title{
SIMULATION OF COMPUTER NETWORK LOAD PARAMETERS OVER A GIVEN PERIOD OF TIME
}

The article deals with the processes of data transmission on computer networks in terms of functional and non-functional indicators of network performance. The purpose of the work is to formalize the characteristics of the computer network that are taken into account in the simulation method and to demonstrate the operation of the method using a test case. The following tasks are solved in the article: substantiation of necessity of application of modeling methods during modernization of computer networks; determining the characteristics of a computer network that affect data transmission processes; formalization of indicators that will be directly applied in the modeling process; description of the test case for the model; iterative simulation of network operation. The following research methods are used: basics of system analysis, models of network functioning, simulation modeling method. The following results were obtained: a computer network considered for functional and non-functional performance characteristics, highlighted characteristics that affect the quality of service delivery, and those that affect the cost of the network topology built. Formulas for calculating the amount of information resource of a network are presented. Formulas for calculating the amount of information resource of a network are presented. The list of basic network characteristics that should be taken into account when modeling network load is justified. Test bench for model work is described. An illustrative example of using a test-based simulation method is calculated. Conclusions: It is concluded that taking into account a large number of network performance indicators will overload the modeling process and it is decided to choose universal indicators of a computer network, which would not depend on the topology of its construction or the type of protocol used. The ability to create a simulation model of a computer network for use in predicting network behaviour when changing the number of requests has been confirmed. Further development of the method will allow us to predict the times of network congestion requests to improve the efficiency of the computer network being upgraded.

Keywords: computer network; simulation; system dynamics; osi model; traffic.

\section{Introduction}

The popularity of Internet telephony has led to the transition to the introduction of services such as video conferencing. This has opened up new horizons for the development of network technologies in the form of "streaming" (streaming) services that allow the transmission of video without loss of quality in online mode to the computers of millions of viewers simultaneously [1]. This creates a huge need to upgrade existing networks both at the software and physical levels. Any network upgrade is a complex and costly process, so solving the problem of reducing the cost of network upgrades is vital for any business looking to optimize their costs [2].

\section{Analysis of recent research and publications}

According to various sources such as internetworldstats.com [3], Cisco [4], Nokia and others, the growth of computer network traffic show a tenfold growth trend over the last decade, with the upward trend increasing year by year. This trend creates the conditions for the development of such areas of research as the analytics of computer networks and network traffic [5,6].

Network simulations are based on simulation models, which are divided into four main types: discrete event models, system dynamics models, dynamic systems modeling, and modeling agents. [7].

System dynamics is a powerful tool for the study of dynamic processes, which allows simulating complex feedback systems [8]. Discrete-event modeling is used if the state of the system changes instantly at appropriate intervals [9]. Dynamic systems' modeling allows us to describe processes in the form of algebraic equations, algorithms, block diagrams and differential equations
[10, 11]. Modeling agents are used to portray decentralized, intelligent systems to obtain information about the interaction of its components [12].

\section{Highlighting unresolved parts of a common problem. The goal of the work}

However, modeling the behaviour of computer networks (CNs) over a period of time is an urgent and unresolved problem. Within the specified subject area, it is possible to analyze the network from different perspectives on its functional properties. One such feature is network load over a period of time. According to the results of a previous study, network traffic is a predictable value over time, so it can be used as a fixed value [13]. This opens up the possibility to apply not only agent modeling to computer networks but also methods of constructing simulation models.

The purpose of the article is to formalize the characteristics of a computer network, which are taken into account in the simulation method, and to demonstrate the operation of the method using a test example. An illustrative example of how this method works will partially simulate the behaviour of a computer network, which in turn will help solve complex business issues related to the allocation of resources for network upgrades [2].

The following tasks are solved:

- substantiation of necessity of application of modeling methods during modernization of computer networks;

- determining the characteristics of a computer network that affect data transmission processes;

- formalization of indicators that will be directly applied in the modeling process;

- a description of a test case for the model; 
- iterative simulation of network operation.

\section{Materials and methods}

When analyzing the effectiveness of $\mathrm{CN}$, it is necessary to consider comprehensively all the factors that affect the quality of its functioning [14]. Let us denote the total set of partial indicators $Q$. It consists of subsets of different sets of metrics $Q_{j}$ (both technical and cost):

$$
Q=\bigcup_{j=1}^{5} Q_{j}
$$

where $Q_{1}$ - a group of indicators of the evaluation of the functioning of the $\mathrm{CN}$ technical equipment; $Q_{2}-$ a set of indicators for evaluating the functioning of the $\mathrm{CN}$ system software; $Q_{3}$ - a group of indicators for estimating the cost of sharing information between nodes; $Q_{4}-$ a group of cost estimators for upgrading and extending $\mathrm{CN}$ nodes; $Q_{5}$ - a group of indicators of costs for the adaptation of $\mathrm{CN}$ software.

Comprehensive consideration of all possible indicators is difficult, so to evaluate the main indicators, it is proposed to select of one main indicator $Q_{O j} \in Q_{j}$ in each subset $Q_{j}$.

Thus, when it comes to user load, it is important to consider the following characteristics of a computer network, namely:

- the capacity of the communication channels;

- delays in data transmission;

- quality of service;

- the number of errors during transmission;

- the cost of building communication channels;

- cost of network nodes.

It is especially important to consider the importance of the network topology as well as the quality and type of communication nodes. Network nodes refer to routers. Industrial routers have the following specifications:

- transmission standard: 3G, 4G (LTE), etc.;

- download speed from the network;

- download speed to the network;

- number of connection ports;

- wireless connection;

- presence of Firewall;

- VPN availability [15].

Also, from a business perspective, routers have a number of physical characteristics that do not affect the data transfer process but significantly affect the cost of a particular device. Physical characteristics are taken into account as follows:

- the operating temperature of the device;

- security of the device from physical impact;

- the size of the device.

All this is important to consider when choosing a particular communication device. For the provider, choosing to route and switching devices is the most difficult and important. Since it is not enough to choose the "best" of the possible options, it is worth choosing the best ones. This allows you to use the most profitable equipment and minimize the cost of purchasing and maintaining it.

As it was previously stated, the network is not a standalone system because it works with the input stream the data transfer requirements. Therefore, the amount of data that must be transmitted over time and at a particular time is an integral feature of a computer network. For further consideration, we can state that:

- the input stream is statistically predictable;

- its frequency can be proven over a period of time;

- its structure is not unique and a certain trend persists despite the geographical location of users;

- the use of the input stream allows building simulation behaviour of the transport network [12].

Because the features of a computer network can be represented by a set of seven levels of OSI, the characteristics are subdivided into those that relate to each individual layer. A generic characteristic that is inherent in each layer and depends on the architecture, physical and protocol characteristics of the network is an Information Resource (IR). It is measured by the number of $N$-level information units provided by the network per time unit [16]. Denote the information resource (IR) provided by the $N$-level network

$$
R^{(N)}=r^{(N)}\left(p^{(N)}\right),
$$

where $r^{(N)}$ and $p^{(N)}$ - respectively, the nodal and communication parameters of the network at the level $N$.

Since the network model is based on the first four levels of the OSI model, let's look at the characteristics of these levels.

At the physical level, the following characteristics can be distinguished:

- $V$ - data transfer speed;

- $l$ - the size of the data block;

- $P$ - probability of data error/distortion.

Then the volume of IR at the physical level [17]:

$$
R^{(1)}=\frac{V(1-P)}{8 l} .
$$

Define the characteristics of the channel layer:

$-1-$ the number of bytes in the frame;

- $t^{m}$ - switching time of modems;

- $\mathrm{p}$ - the probability of distortion of the frame;

- $t^{d}$ - time to receive confirmation of frame sending;

- $n$ - number of physical connections.

Then the size of the information resource at the channel layer:

$$
R^{(2)}=\frac{8 l(1-p) E \sum_{i=1}^{n} R_{i}^{(1)} \sum_{i=1}^{n} V_{i}}{2 t^{m}+t^{d}+70(6+l)},
$$

where $E$-frame size.

At the network level, the most important feature is the protocol structure. This layer virtual channel provides a formula-based IR network [18]: 


$$
R^{(3)}=\frac{\sum_{j=1}^{m} R_{j}^{(2)} l_{j}-U_{I}^{(2)} m}{E_{P}^{(3)}-U_{P}^{(3)}},
$$

where $m$ - the number of second-tier channels that provide frames to the virtual channel $j$;

$U_{I}^{(2)}$ - characteristics of the network channel; $E_{P}^{(3)}$, $U_{P}^{(3)}-$ characteristics of the structure of the main protocol packet.

The transport layer is responsible for the communication of the network ports. The transport station has a volume of resources

$$
R^{(4)}=\operatorname{Ent}\left(\frac{\sum_{r=1}^{k}\left[R^{(3)}\left(E_{I}^{(3)}-U_{I}^{(3)}\right)\right]-l_{4} k}{E_{P}^{(4)}+7}-2 e_{4}\right),
$$

where $k$ - the number of buffered packets of the transport station; $l_{4}$ - the standard size of the transport box management team; $e_{4}-$ the number of unit packets allocated to manage and compile higher levels.

The generalized structure of characteristics associated with certain levels of the OSI model is shown in fig.1.

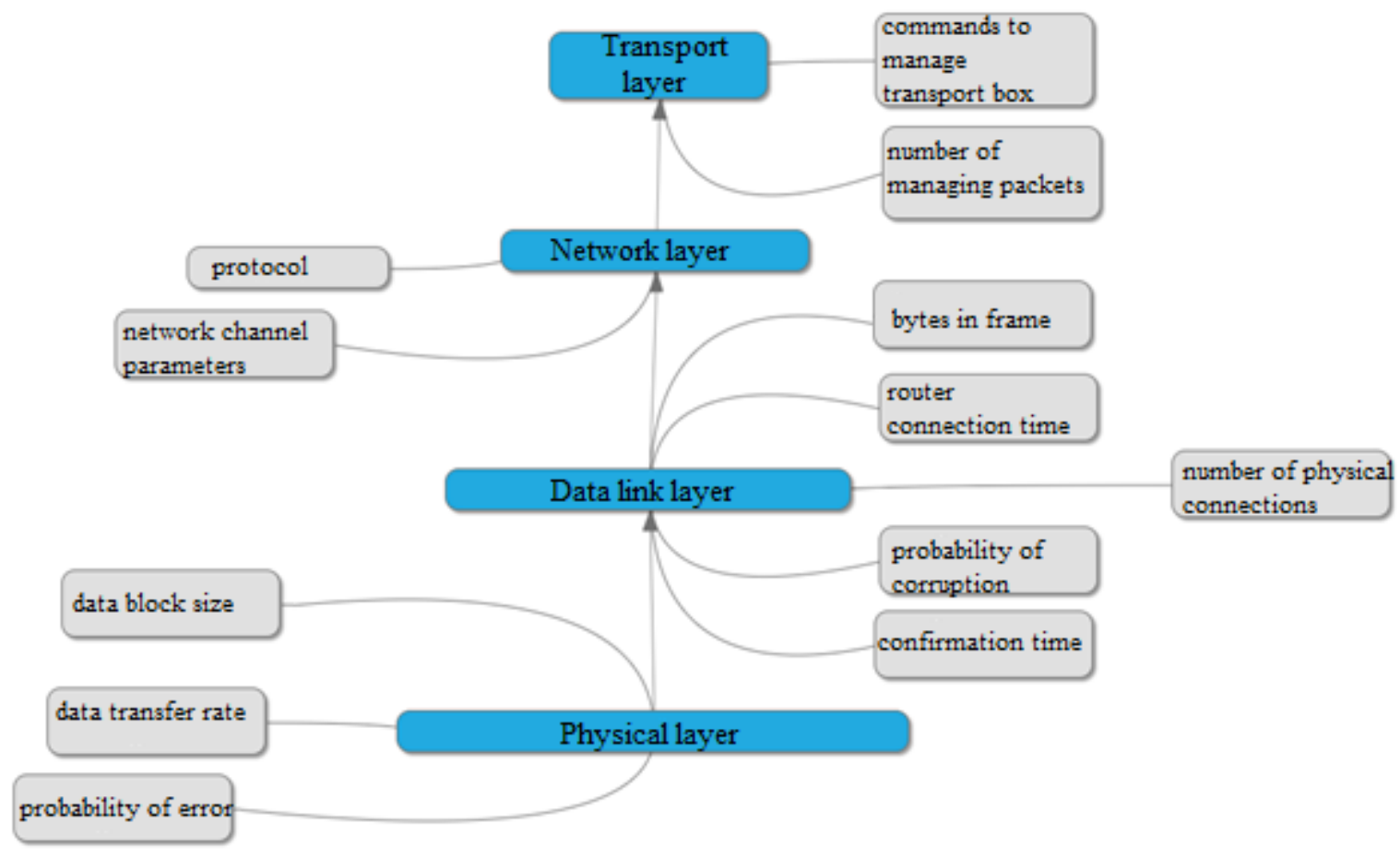

Fig. 1. Characteristics of the lower levels of the OSI model

However, all these characteristics are specific and complicate the modeling process. To simplify the model, it was decided to use abstractions of these characteristics that aggregate several properties at once, or even ignore some of them. The general characteristics of the transport network that will be used for the simulation are given below.

1) Bandwidth is the most important feature of a channel, but it does not characterize other network components. The bandwidth alone is not suitable for modeling network behaviour since it is not used in this way to provide services to end-users. Usually, the term Channel Capacity is used to estimate connection speed [19].

2) Channel power is theoretically the maximum bitrate for data transmission over a communication channel. Because of data transmission errors, using the maximum channel power, the concept of Shannon's channel capacity was introduced, which is theoretically the maximum bitrate for transmitting data to a communication channel without significant errors. Although in fact the Shannon channel power may be exceeded, this usually results in higher losses and does not require a higher transmission rate, this phenomenon is also known as the Shannon law.

Channel power (C) will be further determined by the formula:

$$
C=B \log _{2}(1+S N R),
$$

where $B$ - channel bandwidth, SNR - signal noise ratio (the higher this characteristic, the less noise affects the channel characteristics).

As the channel power is directly proportional to bandwidth, it is often referred to as digital bandwidth. In the future, the bandwidth will mean the Shannon channel power.

3) Latency is an indicator of poor service quality. Delays occur when an attempt is made to transmit data over the bandwidth of a channel. Too much delay causes network congestion, which in turn leads to packets being lost or even blocking the connection. In [2] it is stated that the delay can be calculated using the bandwidth and volume requirements for transmission by the specified 
channel. The delay on the channel $\mathrm{s}$ is defined by the following formula:

$$
d_{c}=\frac{1}{B_{c}-d f_{c}},
$$

where $B_{c}-$ channel bandwidth $\mathrm{c} ; d f_{c}-$ channel input stream $c$.

4) Quality of service is an agreement on the provision of data transmission services over a network. The term also means the probability of a data packet between two nodes in the network. Usually, the quality of service depends on bandwidth, delay, and jitter and packet loss. Most of the quality of service depends on such network services as:

- streaming multimedia programs;

- VoIP telephony;
- remote control;

- and other.

5) The volume of errors during transmission is a generalized parameter that aggregates all kinds of errors that occur during data transmission, such as packet loss, data corruption, etc.

\section{Research results and their discussion}

Here is an example of modeling computer network behavior using the method of predicting the above characteristics [2].

1. The first step in the method is to describe the network topology, that is, the geographical location of the nodes and communication channels. Consider a simplified version of the network topology shown in fig. 2.

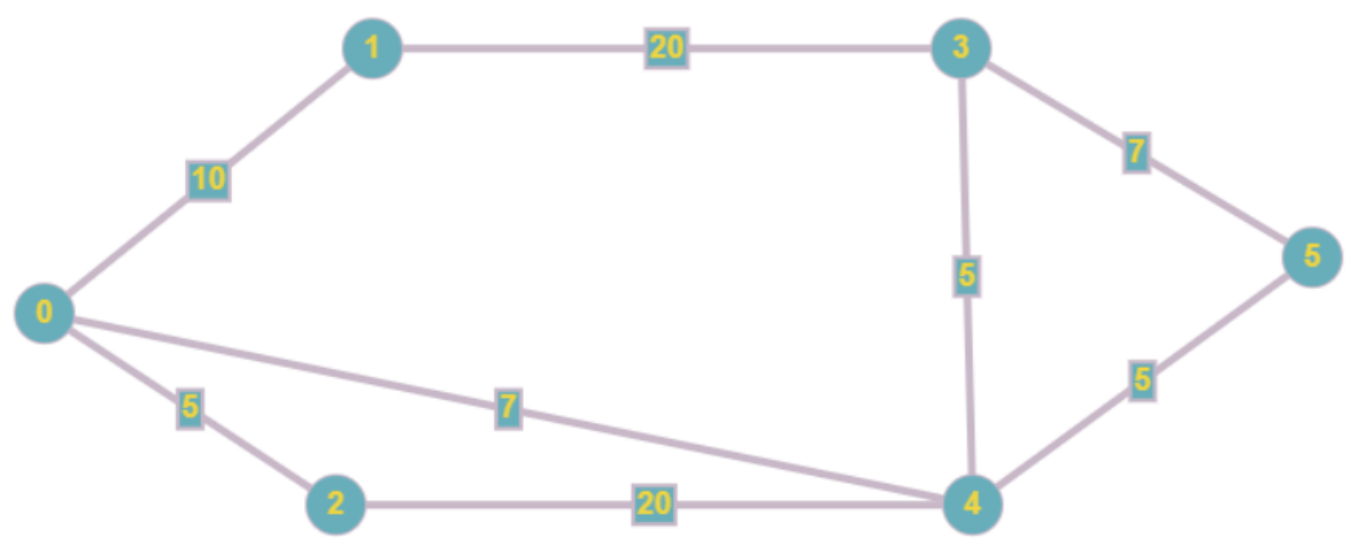

Fig. 2. Test topology of the network

Fig. 2 shows a test layout of a computer network in its original state. The nodes of the graph are the computer network routers and the edges are the communication channels, respectively. Each of the edges is indicated by its maximum channel capacity.

2. The next step is to select the input for modeling. We choose the structure of the input data according to the average load on computer networks in the world [12]. Fig. 3 illustrates the structure of computer network traffic throughout the day. An indirect traffic structure was also built on the basis of information from the world's largest hubs.

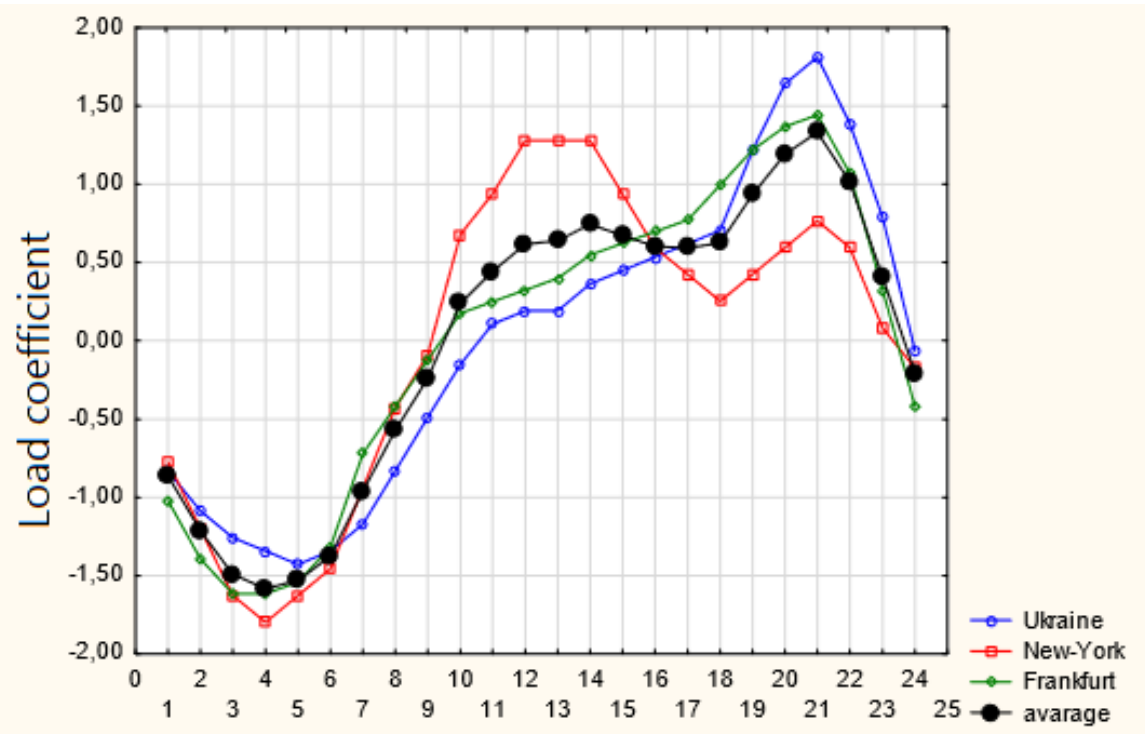

Fig. 3. Average daily computer network traffic 
In the future, we will consider as the main requirement for data transmission the amount of information that must be transmitted within the specified period of time. Taken into account that the test layout shows the absolute values, and in fig. 3 relative, before using they must be bound to the absolute values of the coefficients in fig. 3 . We assume that the value of -2.00 equals 0 data transmission requirements and the value of
+2.00 equals 120 data transmission requirements. One transfer requirement is equal to $1 \mathrm{Mbit} / \mathrm{s}$ bitrate.

For the most ostentatious demonstration of the method, taking into account the differences in network traffic, we take as a basis the time interval from 10 hours to 22 , conditionally simplifying it to five iterations of modeling, where each iteration represents the peak value of traffic dynamics (fig. 4).

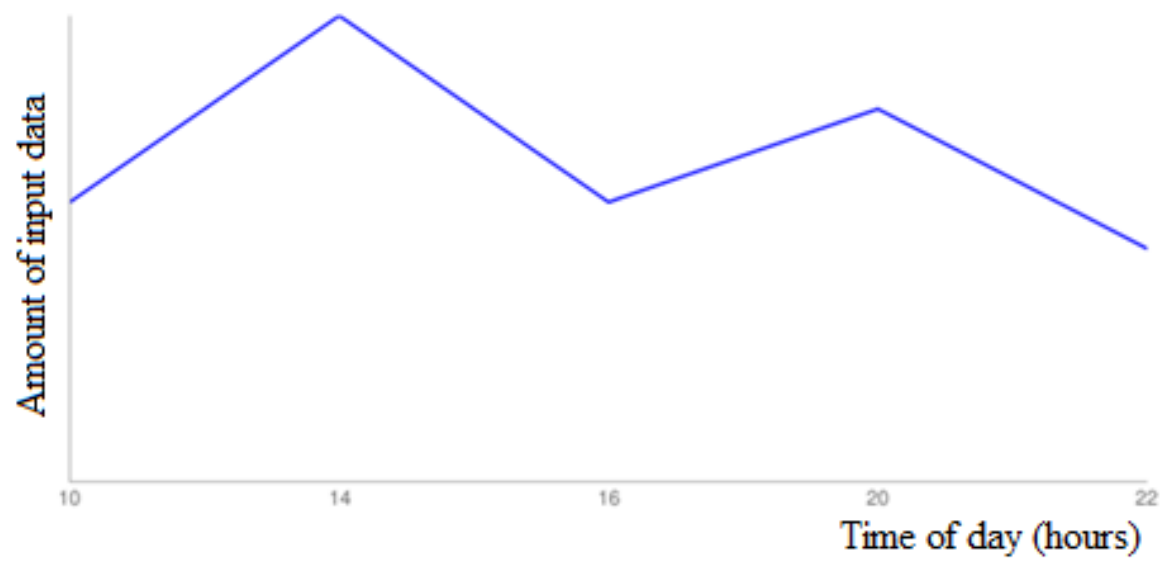

Fig 4. Structure of input data for modeling

3. Distribution of requests for transfer of data by directions. Directions for data transmission will share this load among themselves and can be presented as a table of distribution of requests for data transmission (table 1).

Table 1. Distribution of requests for transfer of data

\begin{tabular}{|c|c|c|c|c|c|}
\hline Direction & $10 \mathrm{am}$ & $2 \mathrm{pm}$ & $4 \mathrm{pm}$ & $8 \mathrm{pm}$ & $10 \mathrm{pm}$ \\
\hline 1 & 5 & 7 & 3 & 7 & 5 \\
\hline 2 & 1 & 3 & 3 & 1 & \\
\hline
\end{tabular}

According to Table 1, there will be two data sessions during the simulation, with the second session ending at 8 pm.

Let the first direction go from zero to the fifth node, and the second direction from the first to the fourth.

4. Construction of the first variant of data transmission routes. At the beginning of the modeling, two routes will be constructed using the Dijkstra algorithm (fig. 5). The solid line shows the route of the first direction, and the dotted line indicates the second, respectively.

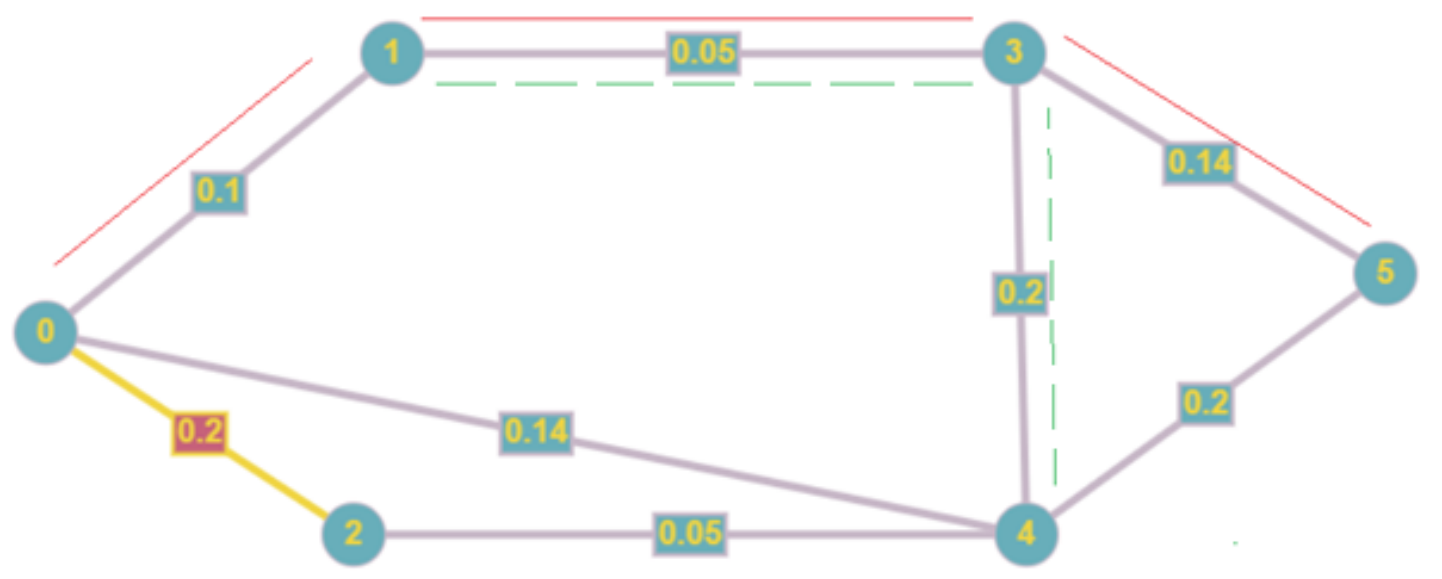

Fig 5. Data transmission routes at the first iteration

5. The next step is to saturate the specified edges with the data transmission requirements of table 1 . According to the algorithm, the requirements are distributed taking into account the "popularity" of the data transmission route. Popularity is the frequency of use of a route during a single data session. The higher is the popularity, the greater is the proportion of the request will be passed along this route. Since only one route was found in the first iteration for each transmission direction, it will pass $100 \%$ of each request.

The state of the network after saturation is shown in fig. 6 . 


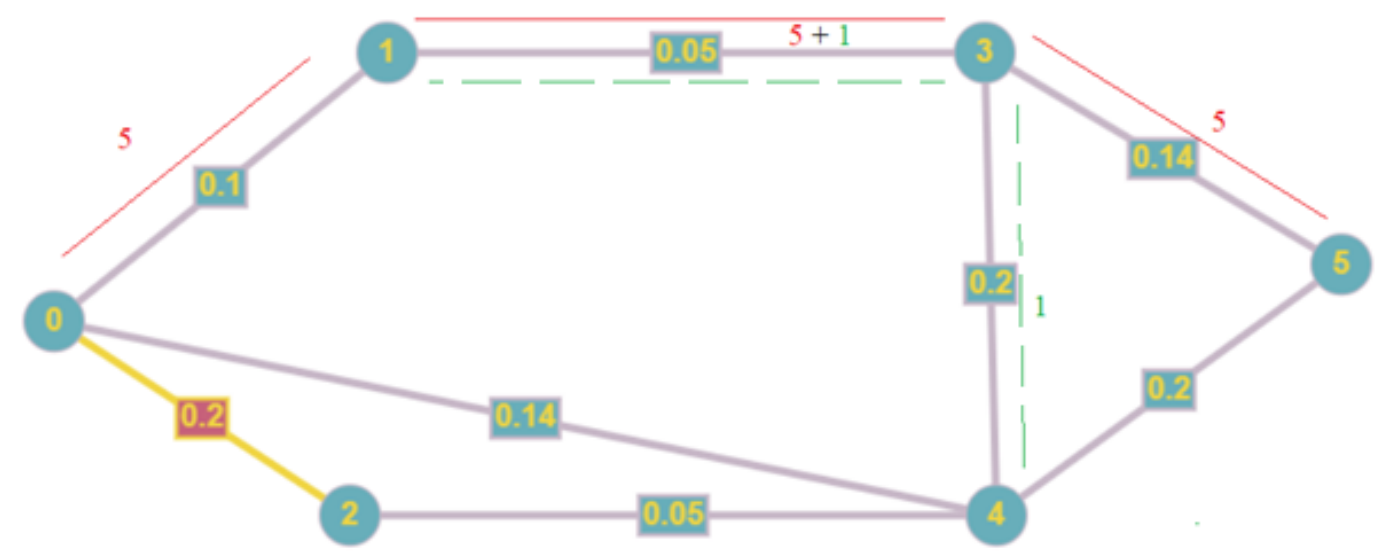

Fig 6. A network saturated with data transfer requirements

Thus, this state of the network is the initial information for the next iteration calculations.

6. It is also important to adjust the table of distribution of requests for data transmission according to the probable losses on the link layer of the transport network. Consider a conditional loss ratio of $15 \%$ [Statistical estimation of TCP packet loss rate from sampled ACK packets] from the specified level of data transfer requirements. On this basis, table 1 after the first iteration will look as shown in table 2.

Table 2. Distribution of data requests after the first iteration

\begin{tabular}{|c|c|c|c|c|c|}
\hline Direction & $10 \mathrm{am}$ & $2 \mathrm{pm}$ & $4 \mathrm{pm}$ & $8 \mathrm{pm}$ & $10 \mathrm{pm}$ \\
\hline 1 & 5 & $\mathbf{7 . 7 5}$ & 3 & 7 & 5 \\
\hline 2 & 1 & $\mathbf{3 . 1 5}$ & 3 & 1 & \\
\hline
\end{tabular}

The state of the network at the second iteration of the simulation (according to the formula of calculation of delays on the communication channels) is shown in fig. 7 .

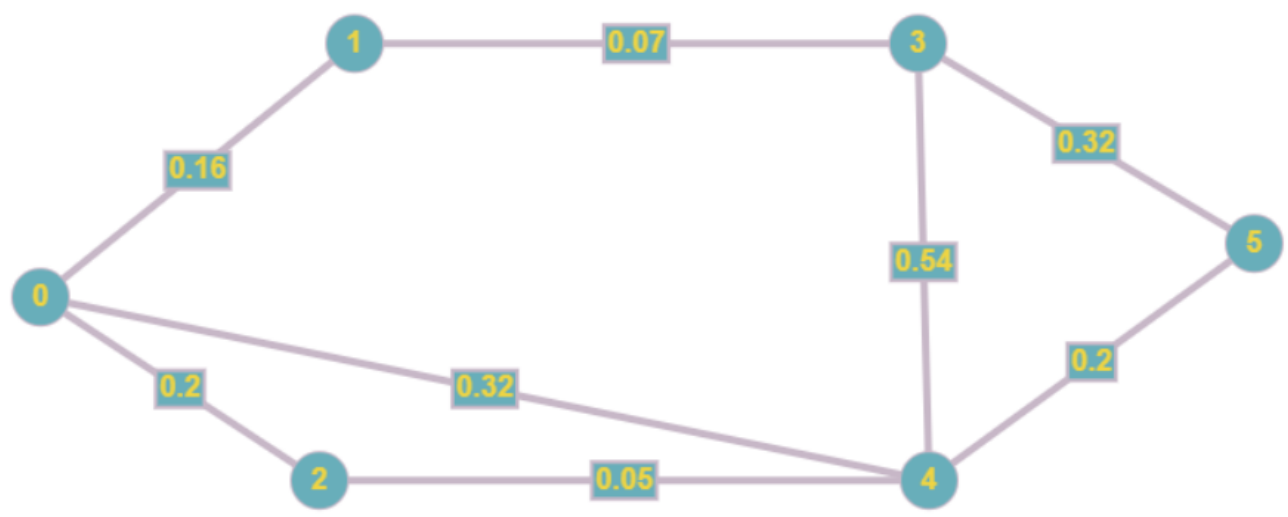

Fig. 7. Network before the second modelling iteration

At this stage, the Dijkstra algorithm is again applied, but since we look for i routes at every $i$-th iteration, we

will now look for two routes for each direction of data transfer (fig. 8).

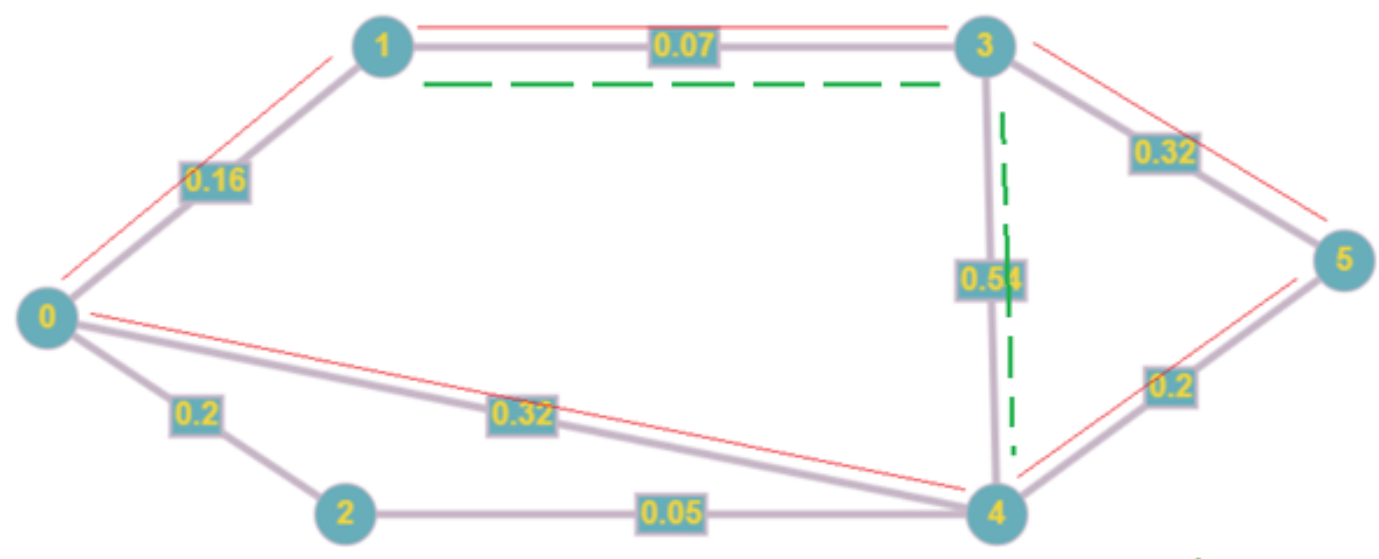

Fig. 8. Data transmission routes on the second iteration 
As can be seen from fig. 8, the routes for the second transfer direction remained unchanged, route $1-3-4$ remained the shortest, but for the first direction two routes were constructed, 0 - 1 - 3 - 5 remained unchanged from the first iteration, and the new route $0-4-5$.
7. Next, we move to saturation of the network with data transfer requirements, but now the requirements for the first direction will be divided into two routes (fig. 9).

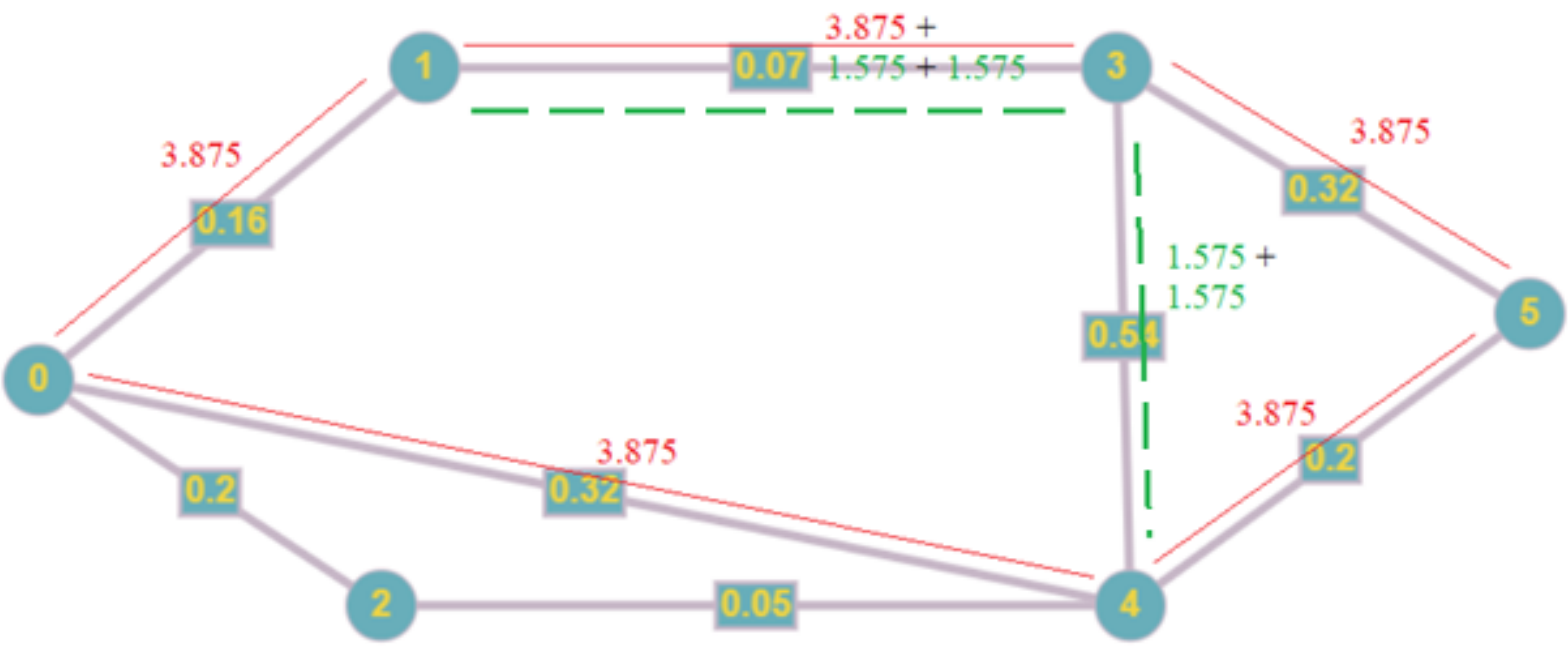

Fig. 9. The network saturated with data transfer requirements

The last step in this iteration will be the redistribution of table 2 according to the channel layer losses (table 3).

Table 3. Distribution of data requests after the second iteration

\begin{tabular}{|c|c|c|c|c|c|}
\hline Direction & $10 \mathrm{am}$ & $2 \mathrm{pm}$ & $4 \mathrm{pm}$ & $8 \mathrm{pm}$ & $10 \mathrm{pm}$ \\
\hline 1 & 5 & $\mathbf{7 . 7 5}$ & $\mathbf{4 , 1 6 2 5}$ & 7 & 5 \\
\hline 2 & 1 & $\mathbf{3 . 1 5}$ & $\mathbf{3 , 4 7 2 5}$ & 1 & \\
\hline
\end{tabular}

All subsequent iterations of the model can be calculated in the same way.

\section{Conclusions}

The main features of computer network performance were discussed. To simplify the simulation and to make the method more versatile, the characteristics were summarized or aggregated into abstract metrics for the computer network.

A demonstration of a pre-built model was performed on a test bench data that was collected based on existing network traffic statistics in the world. As the method does not currently include modeling of transport behavior of the OSI model, it is not possible to illustrate the model adequately. In the following, the calculated model of the transport layer of the computer network will be added to the proposed method. It will be implemented as a "floating window" for traffic redistribution that cannot be transmitted at a specific iteration of the model due to low network bandwidth, high data transfer requirements, etc. This will allow you to analyze the behavior of the network on examples of overloads that will occur in the model and in the real computer network.

\section{References}

1. Reva, A., Davydovskyi, Yu. (2018), "Method of the network topology transformation to quasihomogeneous structure", Radioelectronic and computer systems, No. 2, P. 43-51. DOI: https://doi.org/10.32620/reks.2018.2

2. Davydovskyi, Yu., Reva, A., Malyeyeva, O. (2018), "Method of modelling the parameters of data communication network for its upgrading", Innovative Technologies and Scientific Solutions for Industries, No. 4 (6), P. 15-22. DOI: https://doi.org/10.30837/25229818.2018.6.015

3. Internet World Stats: Usage and Population Statistics, URL: https://www.internetworldstats.com/stats.htm

4. Cisco VNI, "Cisco Visual Networking Index: Forecast and Trends, 2017-2022", URL: https://www.cisco.com/c/en/us/solutions/collateral/service-provider/visual-networking-index-vni/white-paper-c11-741490.html

5. Zhuang, Y., Cappos, J., Rappaport, T., McGeer, R. Future Internet Bandwidth Trends: An Investigation on Current and Future Disruptive Technologies. Secure Systems Lab, Dept. Comput. Sci. Eng., Polytech. Inst. New York Univ., New York, NY, USA, Tech. Rep. TRCSE-2013-0411/01/2013, URL: https://www.semanticscholar.org/paper/Future-Internet-Bandwidth-Trends\%3A-AnInvestigation-Zhuang-Rappaport/5b8d6b99770c8e4045b40ed3f3a5aea1ff202fd2

6. Lakhina, A., Papagiannaki, K., Crovella, M., Diot, C. (2004), "Structural Analysis of Network Traffic Flows", ACM SIGMETRICS Performance Evaluation Review, No. 32 (1), P. 61-72

7. Nevliudov, I., Tsymbal, O., Bronnikov, A. (2018), "Intelligent means in the system of managing manufacturing agent", Innovative Technologies and Scientific Solutions for Industries, No. 1 (3), P. 33-47. DOI: https://doi.org/10.30837/2522-9818.2018.3.033

8. Averin, G. V. (2014), Systemodynamics, Donetsk : Donbass, 403 p.

9. The AnyLogic Company. Discrete Event Simulation, URL: https://www.anylogic.ru/use-of-simulation/discrete-event-simulation/ 
10. Kovalenko, A., Kuchuk, H., Ruban, I. (2018), "Using time scales while approximating the length of computer networks", Innovative Technologies and Scientific Solutions for Industries, No. 2(4), P. 12-18. DOI: https://doi.org/10.30837/25229818.2018.4.012

11. Kosenko, V., Persiyanova, E., Belotskyy, O., Maleyeva, O. (2017), "Methods of managing traffic distribution in information and communication networks of critical infrastructure systems", Innovative Technologies and Scientific Solutions for Industries, No. 2 (2), P. 48-55. DOI: https://doi.org/10.30837/2522-9818.2017.2.048

12. Wilensky, U., William, R. (2015), An Introduction to Agent-Based Modeling, MIT Press, 504 p.

13. Malyeyeva, O., Davydovskyi, Y., Kosenko, V. (2019), "Statistical analysis of data on the traffic intensity of Internet networks for the different periods of time", Second International Workshop on Computer Modeling and Intelligent Systems (CMIS-2019), P. 897910.

14. Poshtarenko, V. M., Andreev, A. Yu., Amal, M. (2013), "Service quality assurance at critical sections of a multiservice network", Newsletter of the National Technical University, No. 60, P. 94-100.

15. Mathematical foundations of the theory of telecommunication systems, in general. ed. V. V. Popovsky, Kharkiv : SMIT Company LLC, 2006, 564 p.

16. Modems and routers for IP-based networks, URL: https://w3.siemens.com/mcms/industrial-communication/en/industrial-remotecommunication/remote-networks/Pages/modems-routers-ip-based-networks.aspx

17. Kozlov, S. V., Ostrikov, Yu. P., Sukhanov, A. L. (2014), "Optimal distribution of information and computing resources based on a two-level criterion", Management of large systems: Sat tr, P. 71-84.

18. Pyatibratov, A. P., Gudyno, L. P., Kirichenko, A. A. (2016), Computing systems, networks and telecommunications, Moscow : Publishing house: "Prospect", 332 p.

19. Saleem Bhatti, "Channel capacity", Lecture notes for M.Sc. Data Communication Networks and Distributed Systems D51 -- Basic Communications and Networks. URL: https://web.archive.org/web/20070821212637/http://www.cs.ucl.ac.uk:80/staff/S.Bhatti/D51notes/node31.html

Received 22.08.2019

\section{Відомості про авторів / Сведения об авторах / About the Authors}

Давидовський Юрій Костянтинович - Національний аерокосмічний університет ім. М. Є. Жуковського «ХАI», аспірант кафедри комп’ютерних наук та інформаційних технологій, Харків, Україна; e-mail: davidovskyi2350@gmail.com; ORCID: https://orcid.org/0000-0003-2813-4169.

Давыдовский Юрий Константинович - Национальный аэрокосмический университет им. Н.Е. Жуковского «ХАИ», аспирант кафедры компьютерных наук и информационных технологий, Харьков, Украина.

Davydovskyi Yurii - National Aerospace N. E. Zhukovskiy University "Kharkiv Aviation Institute", Graduate Student of the Department of Computer Science and Information Technology, Kharkov, Ukraine.

Рева Олександр Анатолійович - кандидат технічних наук, Національний аерокосмічний університет ім. М. Є. Жуковського «XAI», доцент кафедри комп’ютерних наук та інформаційних технологій, Харків, Україна; e-mail: o.reva@khai.edu; ORCID: https://orcid.org/0000-0003-1933-1064.

Рева Александр Анатольевич - кандидат технических наук, Национальный аэрокосмический университет им. Н.Е. Жуковского «ХАИ», доцент кафедры компьютерных наук и информационных технологий, Харьков, Украина.

Reva Oleksandr - PhD (Engineering Sciences), National Aerospace N. E. Zhukovskiy University "Kharkov Aviation Institute", Associate Professor of the Department of Computer Science and Information Technology, Kharkov, Ukraine.

Артюх Олеся Володимірівна - Харківський радіотехнічний коледж, викладач іноземної мови, Харків, Україна; email: olesia.artiuh@gmail.com; ORCID: https://orcid.org/0000-0002-4929-7541.

Артюх Олеся Владимировна - Харьковский радиотехнический колледж, преподаватель иностранного языка, Харьков, Украина.

Artiukh Olesia - Kharkiv School of Radio Engineering, Foreign Language Teacher, Kharkiv, Ukraine.

Косенко Віктор Васильович - доктор технічних наук, доцент, Державне підприємство "Південний державний проектно-конструкторський та науково-дослідний інститут авіаційної промисловості", помічник директор з наукової роботи, Харків, Україна; email: kosv.v@ukr.ua; ORCID: https://orcid.org/0000-0002-4905-8508.

Косенко Виктор Васильевич - доктор технических наук, доцент, Государственное предприятие "Южный государственный проектно-конструкторский и научно-исследовательский институт авиационной промышленности", помощник директора по научной работе, Харьков, Украина.

Kosenko Viktor - Doctor of Sciences (Engineering), Associate Professor, State Enterprise "National Design \& Research Institute of Aerospace Industries", Assistant Director for Research, Kharkiv, Ukraine.

\section{МОДЕЛЮВАННЯ ПАРАМЕТРІВ НАВАНТАЖЕННЯ КОМП'ЮТЕРНОЇ МЕРЕЖІ ПРОТЯГОМ ЗАДАНОГО ПЕРІОДУ ЧАСУ}

Предметом дослідження в статті є процеси передачі даних в комп’ютерних мережах 3 погляду на функціональні та нефункціональні показники якості роботи мережі. Мета роботи - формалізація характеристик комп'ютерної мережі, які враховуються в методі моделювання та демонстрація роботи методу за допомогою тестового прикладу. В статті вирішуються наступні завдання: обгрунтування необхідності застосування методів моделювання під час модернізації комп’ютерних мереж; визначення характеристик комп'ютерної мережі, які мають вплив на процеси передачі даних; формалізація показників, які будуть безпосередньо застосовуватися в процесі моделювання; опис тестового прикладу для 
роботи моделі; ітеративне імітаційне моделювання роботи мережі. Використовуються такі методи дослідження: основи системного аналізу, моделі функціонування мережі, метод імітаційного моделювання. Отримано наступні результати: комп'ютерна мережа розглянута 3 боку функціональних та нефункціональних характеристик ефективності, виділені характеристики, які впливають на якість надання послуг, а також такі, що впливають на вартість побудованої мережевої топології. Представлені формули обчислення обсягу інформаційного ресурсу мережі. Обгрунтовано перелік основних характеристик мережі, які мають бути ураховані при моделюванні навантаження мережі. Описаний тестовий стенд для роботи моделі. Розрахований ілюстративний пример використання методу моделювання на основі тестових даних. Висновки: Зроблено висновок, що урахування великої множини показників ефективності мережі перевантажить процес моделювання та прийнято рішення обрати загально-універсальні показники комп'ютерної мережі, які б не залежали від топології ії побудови, або типу протоколу, який використовується. Підтверджено можливість створення імітаційної моделі роботи комп’ютерної мережі для її використання при прогнозуванні поведінки мережі під час зміни кількості запитів. Подальший розвиток методу дозволить прогнозувати моменти перевантаження мережі запитами для підвищення ефективності використання комп’ютерної мережі, що модернізується.

Ключові слова: комп’ютерна мережа; імітаційне моделювання; системна динаміка; модель OSI; трафік.

\section{МОДЕЛИРОВАНИЕ ПАРАМЕТРОВ НАГРУЗКИ КОМПЬЮТЕРНОЙ СЕТИ В ТЕЧЕНИЕ ЗАДАННОГО ПЕРИОДА ВРЕМЕНИ}

Предметом исследования в статье являются процессы передачи данных в компьютерных сетях с точки зрения на функциональные и нефункциональные показатели качества работы сети. Цель работы - формализация характеристик компьютерной сети, которые учитываются в методе моделирования и демонстрация работы метода с помощью тестового примера. В статье решаются следующие задачи: обоснование необходимости применения методов моделирования при модернизации компьютерных сетей; определения характеристик компьютерной сети, которые влияют на процессы передачи данных; формализация показателей, которые будут непосредственно применяться в процессе моделирования; описание тестового примера для работы модели; итеративное имитационное моделирование работы сети. Используются такие методы исследования: основы системного анализа, модели функционирования сети, метод имитационного моделирования. Получены следующие результаты: компьютерная сеть рассмотрена со стороны функциональных и нефункциональных характеристик эффективности, выделенные характеристики, которые влияют на качество предоставления услуг, а также те, которые влияют на стоимость построенной сетевой топологии. Представленные формулы вычисления объема информационного ресурса сети. Обоснованно перечень основных характеристик сети, которые должны быть учтены при моделировании нагрузки сети. Описанный тестовый стенд для работы модели. Рассчитан иллюстративный пример использования метода моделирования на основе тестовых данных. Выводы: сделан вывод, что учет большого множества показателей эффективности сети перегрузит процесс моделирования и принято решение избрать обще-универсальные показатели компьютерной сети, которые бы не зависели от топологии ее построения, или типа протокола, который используется. Подтверждена возможность создания имитационной модели работы компьютерной сети для ее использования при прогнозировании поведения сети при изменении количества запросов. Дальнейшее развитие метода позволит прогнозировать моменты перегрузки сети запросами для повышения эффективности использования компьютерной сети, которая модернизируется.

Ключевые слова: компьютерная сеть; имитационное моделирование; системная динамика; модель OSI; трафик.

\section{Бібліографічні описи / Bibliographic descriptions}

Давидовський Ю. К., Рева О. А., Артюх О. В., Косенко В. В. Моделювання параметрів навантаження комп'ютерної мережі протягом заданого періоду часу. Сучасний стан наукових досліджень та технологій в промисловості. 2019. № 3 (9). C. 72-80. DOI: https://doi.org/10.30837/2522-9818.2019.9.072.

Davydovskyi, Yu., Reva, O., Artiukh, O., Kosenko, V. (2019), "Simulation of computer network load parameters over a given period of time", Innovative Technologies and Scientific Solutions for Industries, No. 3(9), P.72-80. DOI: https://doi.org/10.30837/2522-9818.2019.9.072. 